\title{
Maciej Stradomski
}

Poznań University of Economics and Business

e-mail: maciej.stradomski@ue.poznan.pl

ORCID: 0000-0001-7570-8730

\section{Katarzyna Schmidt}

Poznań University of Economics and Business

e-mail: katarzyna.schmidt@ue.poznan.pl

ORCID: 0000-0002-5310-1038

\section{SECULAR STAGNATION AND COVID-19}

DOI: $10.15611 / \mathrm{pn} .2020 .4 .15$

JEL Classification: E20, E40, E66, O11

\section{(C) 2020 Maciej Stradomski, Katarzyna Schmidt}

This is an open access article distributed under the Creative Commons Attribution-NonCommercial-NoDerivs license (http://creativecommons.org/licenses/by-nc-nd/3.0/)

Quote as: Stradomski, M., and Schmidt K. (2020). Secular stagnation and COVID-19. Prace Naukowe Uniwersytetu Ekonomicznego we Wrocławiu, 64(4).

\begin{abstract}
The main aim of the article is to start a discussion about the pandemic COVID-19 in the context of secular stagnation. The secular stagnation phenomenon was reintroduced by L. Summers in 2013, who claimed that after the global financial crisis of 2007-2009, advanced economies were trapped in an era of low and sluggish growth and a low-interest rates environment. Now, with the occurrence of coronavirus many things have changed, therefore the authors tried to analyse the structural determinants of secular stagnation and the potential impact of the crisis on these factors. The authors concluded that the coronavirus crisis might be a breaking point that will change the global economy but the character and novelty of the crisis make it difficult to predict future outcomes.
\end{abstract}

Keywords: secular stagnation, crisis, pandemic, COVID-19.

\section{Introduction}

Just as back in 1934 A. Hansen could not have predicted the outbreak of World War II in the late 1930s, so in 2020 L. Summers could not have foreseen the outbreak of COVID-19, presumed to be about to upend the world order as we know it. However, unlike in the case of World War II, which saw economies devastated by humankind, today's cataclysm is a purely biological and medical phenomenon in which the role of humans has been reduced to mere containment. Hence, notes W. Frąckowiak 
[2020] "in addition to provoking enormous spending and causing huge material losses, the coronavirus is punishing human vanity and crushing people's sense of being almighty and invincible masters of the world relying on perpetual growth and endless innovation".

As World War II drove away the spectre of secular stagnation invoked by Hansen, the demand for military supplies, the surge in public spending and the post-war demographic boom fueled economies that had struggled in the face of flagging demand [Marczewski 2017]. Will COVID-19 also lift the world out of its doldrums, as described by Summers [2014]? Are we in for a revolution? Will a new paradigm rooted in the human experience of suffering, death and loss sweep into oblivion its predecessor that originated in Mediterranean culture and which embodies the principle of "more, faster, better"?

This article aims to discuss all of the above issues. Through an in-depth analysis of the phenomenon of secular stagnation and the factors considered to contribute to the entrenchment of secular stagnation in developed economies, the authors address the question of whether the COVID-19 pandemic can be a shock that causes economies to change course and lift them out of their current sluggishness.

The article is a theoretical reflection comprising five sections. Section 1 discusses secular stagnation by comparing its original understanding with the contemporary view. Section 2 focuses on the structural factors that economists believe to have contributed to the emergence and perpetuation of secular stagnation. The following section presents the negative consequences of secular stagnation. Section 4 attempts to identify the impacts of the COVID-19 outbreak on the structural factors that underpin secular stagnation, i.e. it seeks to answer the question that constitutes the main goal of the paper. The final section summarizes the key conclusions of the authors, as arrived at in this study.

\section{Secular stagnation in 1934 and 2013}

The notion of secular stagnation was first proposed by A. Hansen in 1934 [Hansen, 1934] and then more broadly presented in his 1938 speech to the American Economic Association [Hansen 1939] ${ }^{1}$ as an attempt to define the situation the United States economy was facing at the time.

In his view [1939, p. 4] secular stagnation was like "sick recoveries which die in their infancy and depression which feed on themselves and leave a hard and seemingly immovable core of unemployment".

This rather skeptical assessment of the economy of the time can be put down to several reasons. Firstly, as observed by Hansen, despite the end of the Great Depression of 1929-1933, global production persisted below pre-crisis levels [Marczewski 2018]. Secondly, unemployment rates remained high, and thirdly,

\footnotetext{
${ }^{1}$ A year later, an extended version of this speech appeared in The American Economic Review.
} 
population growth was in decline, magnifying the demographic drag on the American economy [Mączyńska 2015]. Although, according to Gordon [2014], Hansen made his observations before the arrival of the concept of potential and real GDP, the state of the American economy he was describing corresponded to the nearly $20 \%$ gap between actual and potential GDP.

In addition, one should take note of the factors that, according to the economists of the time, contributed to economic growth and progress. Hansen [1939] listed three basic constituent elements of economic progress: (a) innovation, (b) the discovery and development of new territory and new resources, and (c) the growth of population. In the 1930s, each of these factors lost its relevance. Major geographical discoveries came to a halt in the nineteenth century, ${ }^{2}$ while many groundbreaking and significant inventions were made prior to $1930^{3}$ (or such at least was the prevailing view at the time), while population growth was slowing. Given the above, Hansen's theory of the advent of secular stagnation appeared to be correct.

Perhaps the prophecy of secular stagnation would have come true had it not been for the outbreak of World War II, which thoroughly reset the stage. As insufficient demand became a thing of the past due to huge public orders, investment focused on military needs, and the post-war population boom made the problem of ageing societies irrelevant.

With some exceptions, disregard for secular stagnation continued until 2013. Although a number of twentieth-century authors ${ }^{4}$ made references to the Hansenian doctrine in their writings, the doctrine never received the attention it was given in 2013 when, in a speech at the 14th Annual IMF Research Conference, L. Summers used the two-word term to describe the American economy.

Similarly, as in Hansen's works the secular stagnation concept followed the Great Depression of 1929-1933, Summers relaunched the debate on secular stagnation in the 21 st century after the global financial crisis of 2007-2009. This Harvard University professor noted that well-known economic mechanisms of the post-crisis recovery of states failed in developed economies, and that real GDP persisted below its potential levels [Summers 2013].

In addition, Summers [2013] argued that the world was experiencing a drop in the natural interest rate (the equilibrium interest rate) to well below zero, showing that the hitherto standard monetary policy was in fact ineffective.

Further in the discussion, Summers [2016] claimed that developed countries struggled with a chronic imbalance between savings and investments caused by a growing propensity to save combined with a decreasing propensity to invest. As a consequence, surplus savings reduce demand, limiting the growth of GDP and

\footnotetext{
${ }^{2}$ The last continent to be discovered (in the nineteenth century) was the Antarctic, which was explored thoroughly in the early twentieth century [PWN].

${ }^{3}$ See: [Dach 2011, p. 23].

${ }^{4}$ For instance: [Higgins 1950, pp. 160-166; Samuelson 1988, pp. 3-19].
} 
inflation, while the disequilibrium between savings and investments drags down the natural real interest rate, which cannot be accompanied by falls in the real interest rate due to the zero-interest rate limit [Marczewski 2018].

Such observations led the authors to conclude that the current general economic stagnation cannot have been caused solely by the global crisis of 2007-2009, and that the root causes of that stagnation lie much deeper and are structural in nature, which makes the slowdown acquire the characteristics of secular stagnation.

Although many outstanding economists took issue with his assertions ${ }^{5}$, the years of sluggish economic growth that followed amidst low if not negative interest rates meant that, according to Summers [2018, p. 228], “(...) events since I started advocating the secular stagnation view have tended to confirm its predictions and reject those of its critics."

\section{The causes of contemporary secular stagnation}

As mentioned in Section 1, Summers noted that the causes of today's secular stagnation are much more complex and that secular stagnation should not be associated solely with the global financial crisis, although it undoubtedly accelerated it greatly. According to economists, sluggish growth and low interest rates have resulted from the structural factors that fall into the following categories:

a. higher propensity to save,

b. lower propensity to invest,

c. changes in investment portfolios.

The general population's higher propensity to save is due to several reasons. Firstly, a number of demographic factors come into play. Longer life expectancy and declining death rates have left many economies grappling with societal aging. Although these challenges mainly affect developed economies, they increasingly also bear down on developing economies, such as China. Given that the retirement age has not been raised accordingly, ageing societies end up hoarding capital to live off it after retirement [Bean et al. 2015].

Secondly, the growing propensity to save translates into greater inequalities in the distribution of income [Gordon 2014]. Due to such growing discrepancies, a small group of people comes into the possession of ever greater capital resources. Such individuals are considerably more likely to save than low-income earners. As a consequence, the greater the inequalities in the distribution of income, the greater the aggregated social propensity to save, the lower the consumption and consequently - the lower the equilibrium real rate [Rachel and Smith 2015].

The third driver of the global increase in savings is the creeping financial integration between the world's economies and China and with other economies characterized by a high total savings ratio. Hence, the financially integrated savings

${ }^{5}$ See: [Teulings and Baldwin (eds.) 2014]. 
ratio, which remained relatively stable up until 2000, has climbed steeply during the last two decades [Bean et al. 2015].

The lower propensity of market participants to invest is the second much quoted factor for secular stagnation. The key cause of lower investment is a decrease in relative prices of capital goods observed over the years [Bean et al. 2015; Eichengreen 2015; IMF 2014a; Rachel and Smith 2015]. Thus, a given investment project currently requires less capital input (which makes it account for a smaller share of GDP). On the other hand, the extra projects conducted to take advantage of cheaper capital hardly offset the overall decline in investment value [Eichengreen 2015]. This is confirmed by IMF estimates (2014a) showing that the relative prices of capital goods, investment value (expressed as a percentage of GDP) and investment volume (also expressed as a percentage of GDP) decreased steadily between 1980 and 2013.

Another factor is the drop in public investment. The decrease can be attributed to two developments: one being that, riven by in-fighting, governments lose their ability to approve large investment projects, the other being that voter preferences are found to be swaying in favour of private investment [Rachel and Smith 2015]. The IMF's calculations [2014b] demonstrate that the slump in public investment has continued for the last three decades (decreased public capital as percentage of GDP) in both developed and developing economies.

The third reason for the decline in investment is the lack of groundbreaking innovations [Bean et al. 2015]. This conclusion was postulated by R. Gordon [2012], who explained that the rapid rise in production and investment seen over the last 250 years has been driven by three unique innovations: the invention of the steam engine and the railroads, electricity and the internal combustion engine, as well as the digital revolution. Gordon [2012] pointed out that any further innovations that would so profoundly change the lives of humanity seem unlikely, and that the main effect of the current development of digital technologies, new computers and phones is to increase consumption with only slight effect on greater efficiency or productivity.

The final major factor that economists consider to have contributed to economic stagnation and the plunging interest rates is a change in the preferences of market participants, a shift towards increased demand for so-called safe assets [Bean et al. 2015; Rachel and Smith 2015], and a reduced supply of such assets [Caballero and Fargi 2014; Golec and Perotti 2017]. Shifts in the curves of the demand for or the supply of safe assets put pressure on the rate of return on safe assets, whose lower limit is subject to the zero confine. Thus, the increased demand for safe assets and their smaller supply freeze interest rates at low levels blocking the self-regulatory mechanism that would otherwise restore an equilibrium in the prices of such assets.

Each of the above-mentioned problems had been in the making for a considerable time prior to the onset of the global financial crisis. Once economies went into meltdown, the extent and magnitude of the problem reached unprecedented proportions. The crisis fueled uncertainty among market participants causing them to 
lose confidence in financial institutions and the instruments they offered and driving them to be even more likely to save and more reluctant to invest. All this gives rise to the question of whether the developments unfavorable for economic progress observed over the years were unavoidable, or whether in fact could have been avoided by abandoning the inept economic policies pursued by the states. As early as 2014, B. Eichengreen wrote that if the United States were confronted with secular stagnation, it would be solely as a consequence of a self-fulfilling prophecy that would come true if the country failed to understand and remedy the infrastructural, educational and training shortcomings with which its economy is riddled.

\section{The adverse effects of secular stagnation}

For economies, secular stagnation is evidently undesirable. Slow growth, no breakthrough discoveries, stagnation, saving chronically prevailing over investment and permanently low interest rates have a number of negative consequences that, if ignored, further exacerbate and perpetuate stagnation.

One significant negative consequence of such developments is the inability to restructure the economy after the global financial crisis. The low interest rates introduced by central banks were designed to stimulate economic growth. The classic monetary transmission mechanism did not work as expected. Each successive reduction strengthened the conviction of market participants that they were living in an age of cheap money. Given access to cheap financing, businesses are under less pressure to increase productivity, which can lead to an overall decline in sector efficiency. Additional contributions to the problem are made by the so-called zombie companies [Caballero, Hoshi, and Kashyap 2008] which, if faced with high or normal interest rates, would collapse without additional funding. With their inefficiency and unprofitability, such companies distort competition weakening entire industries.

On the other hand, near-zero interest rates enable almost all businesses to repay their debts while encouraging banks to engage in ever riskier ventures [Rzońca 2014]. This, in turn, erodes the assets of commercial banks, which endlessly postpone their restructuring. Meanwhile, aware of the poor condition of the banking sector, central banks continue to maintain low interest rates to give financial institutions ample time to restructure. The resulting downward spiral has the effect of perpetuating economic woes.

The other adverse effect of this phenomenon is the large deficit maintained by fiscal authorities. There are at least two arguments for doing so. One is that low interest rates make borrowing cheap not only for businesses but also for the state treasury, thus encouraging fiscal expansion. Secondly, due to the near-zero interestrate policy, persistently slow rise in manufacturing productivity and weak total demand cause the fiscal authorities to view any additional reductions in public expenditure as a threat to a fragile recovery [Rzońca 2014]. Thus, confronted with excessive indebtedness, economies may slip into a debt spiral. According to research 
by Greenlaw, Hamilton, Hooper and Mishkin [2013], the economies whose debt exceeds $80 \%$ of GDP are highly vulnerable to falling into such debt spirals, especially if they maintain high current account deficits.

Another severe adverse effect of secular stagnation and of operating in a lowinterest-rate environment are the compromised options of central banks to deploy their instruments [Forbes 2015]. Up until now, the lowering of the central bank's basic interest rates has been the go-to response for restoring balance in the economy. Once interest rates are approximate to zero, it becomes obvious that central banks do not have much room for manoeuvre to make further reductions. The persistence of near-zero interest rates for extended periods puts pressure on central banks to engage in massive quantitative easing (low interest rates lead to low money supply dynamics even if the monetary base is aggressively increased) driven by high demand for liquidity from both businesses and banks [Rzońca 2014]. The negative consequences of such measures are twofold. On the one hand, quantitative easing has the effect of reducing long-term interest rates, which perpetuates the near-zero interest rate policy. On the other, by means of massive quantitative easing, the central bank subsidizes insolvent banks, which in turn "lands it under increased pressure to support other financial institutions and sectors by, in particular, guaranteeing that the interest rate will remain close to zero well into the future" [Rzońca 2014, p. 42]. As a result, we are again faced with a spiral that perpetuates the low-interest-rate policy while impeding economic recovery and the restoration of rapid growth.

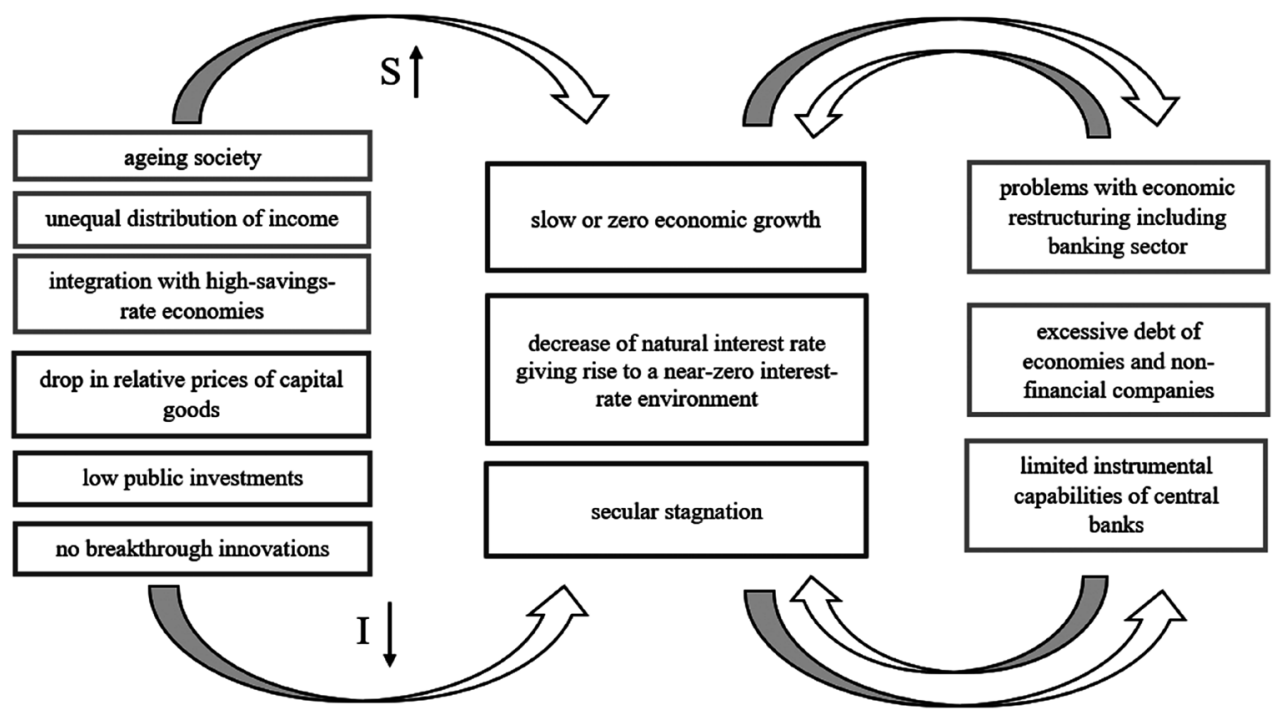

Fig. 1. Secular stagnation, its causes and consequences as a self-perpetuating mechanism

Source: own research partially based on [Bean et al. 2015; Rachel and Smith 2015; Rzońca 2014; Teulings and Baldwin 2014]. 
To summarize the above, the figure 1 presents the structural factors contributing to secular stagnation as well as their effects and negative consequences. The arrows show the feedback mechanism where (S) denotes saving and (I) denotes investment.

\section{The impact of COVID-19 on secular stagnation}

The COVID-19 pandemic has delivered a major blow all across the globe which, unlike the crises before it, did not originate in the financial community. The COVID-19 disaster is affecting both the demand and supply sides of economies, compelling businesses to restructure their operations and profoundly revise their objectives.

Ever since the pandemic first broke out, economists have been trying to gauge its potential effects and construct scenarios of events that depend on the way the epidemic is going to unfold. The economists such Smit, Hirt, Buehler, Lund, Greenberg and Govindarajan [2020] of McKinsey have devised as many as nine such scenarios based on two scales, one of the efficiency of pandemic management in medical terms and another of such efficiency in economic terms. The severity of the impacts of the COVID-19 pandemic on market participants will hinge on how well each economy does in these two fields.

The sheer number of the scenarios shows just how unpredictable and varied the post-pandemic situation may be. In addition, given how fast the circumstances are changing, any indications, forecasts and recommendations proposed in early March tend to be obsolete. Such great uncertainty and the lack of tried and tested response mechanisms for disasters of this type also result from the fact that the origins of the crisis we are experiencing differ completely from those known to modern society. The majority of the wars and climate problems experienced in recent decades have been local in scope and, as such, did not disrupt global value chains. The financial crisis of 2007-2009 mostly struck the financial sector with little effect on the lives, habits and plans of entire societies across the world.

How then will COVID-19 end? Will it be an economy-cleansing catharsis? Needless to say, neither question can be answered definitively, and yet it is vital to launch a debate to provide an alternative perspective on the issue.

Given that economies struggled with secular stagnation even before the outbreak of COVID-19, chances are that a shock of the magnitude represented by the pandemic will hit economies all the harder when compounded by the structural factors enumerated above. What follows is a discussion of such factors in connection with COVID-19 and its potential impacts.

\subsection{More savings}

One of the underlying causes of the above-mentioned excessive propensity to save, which propels secular stagnation, is an ageing society. The current mortality rate for 
COVID-19, which stands at 4.5\% [Lovelace Jr. 2020], exceeds that of the seasonal flu by 4.4 p.p. Although the notorious Spanish flu left in its trail a death toll far greater than World War I, its mortality rate was lower than that for COVID-19 (2.5\%). The highest mortality rates have been reported for such viruses as Ebola (over 50\%) and MERS (35\%), both of which had a significantly smaller geographic coverage. COVID-19 kills people of all ages, with older people, people with compromised immune systems and people with co-morbidities being particularly vulnerable [Centers for Disease Control and Prevention 2020]. Therefore, a lingering pandemic coupled with poorly targeted medical assistance and a misguided or delayed health and safety response can drive up death tolls and shift societal demographics.

Another reason for the chronic increase in savings are widening income gaps. In an effort to protect their citizens from the pandemic, many governments have imposed lockdown and confinements measures, closing schools, universities, restricting land, air and sea travel and even sealing state borders. Restrictions have also been imposed on service sectors resulting in the shutdowns of hotels, travel agencies, beauty parlors, hair salons, etc. Many people have lost their jobs overnight. Deprived of income, businesses (e.g. the British airline Flybe) began to collapse [Baldwin and di Mauro 2020]. Many saw their supply chains disrupted only to find that state aid is inadequate. Hence, it appears that the COVID-19 pandemic is unlikely to reduce income inequalities. On the contrary, it may actually widen the existing income gaps between the poor and the rich.

The third structural factor to have contributed to the rise in global savings in recent years is the financial integration of economies with China and other states that are characterized by high savings rates, such as India. G. Rishi says [Baldwin and Tomiura 2020, p. 64] that "in the last two decades, China became the factory of the world. Consumer packaged goods, automotive, apparel, high-tech. I can't tell you which sector is not getting impacted". In the face of the pandemic, such tight integration and economic dependence on Far Eastern countries has severe implications for the further development of businesses in Europe. Firstly, the closures of borders and workplaces and other mandatory restrictions have disrupted the supply chains of many companies. Secondly, such disrupted supply chains have forced enterprises to restructure their operations by switching to local suppliers. Their non-dependence on Asian suppliers may leave supply chains changed lastingly even post-pandemic. The question of whether the world will turn away from globalization was posed by B. Javorcik [2020], who noted that the global rules of the game have been weakened and that the diversification of value chains has become an unavoidable solution to the problems of many companies.

Another factor that can potentially affect globalization and market integration is the legislation passed by outbreak-affected states. In attempts to minimize the adverse effects of the crisis and its impacts on industry, many states (including Poland and Germany) have adopted temporary laws intended to protect and support domestic business. Some of their aims are meant to protect enterprises against 
hostile takeovers, which could become more common as corporations swoop in to take advantage of the bargain valuations of many listed companies. Low corporate valuations would certainly create opportunities for multinational giants that could jump at the opportunity to complete mergers and acquisitions. It appears that actions of this type, i.e. the centralized locking of international capital flows, may disintegrate and either slow or temporarily freeze globalization.

One should bear in mind that the COVID-19 pandemic may influence social mindsets and the willingness of populations to integrate. Even today, globalization, ease of travel and significant market integration are blamed for the rapid spread of the virus across the globe. The fear is that "in times of rising nationalism and populism, people's fears and suspicions of others might become a force for disintegration worse than Brexiteers" [di Mauro 2020, p. 33].

\subsection{Drop in investment}

The other category of structural factors associated with secular stagnation is the decline in investment precipitated by a decrease in the relative prices of capital goods, among others. Disrupted supply chains forcing companies to search for local suppliers (who often turn out to be more expensive) and overhaul business strategies may send the prices of some goods up. On the other hand, the uncertainty and fears caused by the coronavirus pandemic drive households and businesses alike to either delay or altogether abandon their investment plans [Boone 2020], resulting in a global reduction in the demand for investment. During the pandemic, both society and industry focus on satisfying their basic needs, which means purchasing the goods and performing the activities that are vital for daily life and guarantee survival. This makes the net effect of the above factors and their ultimate impact on the prices of capital goods difficult to predict.

Another factor for lowering investment, i.e. low public spending, may lose its relevance in the COVID-19 pandemic. Many economists agree that the shape of economies in the post-pandemic world will depend on the fiscal and monetary authorities. The key to mitigating the severe effects of the collapse will be to properly target public expenditure, provide fair and effective aid to businesses, and proactively stimulate the economy with state spending. According to Boone [2020], government spending should first go to the medical and healthcare sectors followed by distressed households and businesses. However, as massive state aid packages increase public debt in economies, they do little to promote investment. The current outlays, which come largely in the form of emergency assistance, fail to hasten economic recovery. It seems that once the crisis is over, which is when few enterprises will be in a position to make investments, the role of the state will be to skillfully stimulate economic growth through public procurement and ongoing investments.

The final constituent element in the falling investment category is the lack of groundbreaking innovations. The biological and medical nature of the crisis has 
relegated many areas of the economy to the virtual world. A great proportion of enterprises are only able to carry on doing business thanks to the existence of the Internet. Home offices have grown popular while ossified administrative systems are being fast-tracked toward digitization. Glapiak [2020] states that "the coronavirus will forever change the face of the world as we know it, both at work and in personal life. As technology establishes a much stronger presence in our lives, our habits are bound to change."

As true as the above statement appears, one might wonder whether such changes will be revolutionary and will affect the productivity of labour. In both the financial and non-financial sectors, service organizations hasten to offer new mobile solutions that will enable market participants to function normally while minimizing the need to leave their homes. The ever faster automation of manufacturing, autonomous vehicles and drones used for deliveries, a booming 3D printer industry, and accelerated development of preventive medicine are just some of the many areas in which the pandemic has sparked growth. Such forced progress may strengthen the economy prompting people to revise their social and economic priorities.

In addition to the above issues, proper consideration is required for the issue of low interest rates, as clearly emphasized by Summers in his discussion of secular stagnation. In the wake of the global financial crisis of 2007-2009, many economies, including that of the eurozone, found themselves mired in a low interest rate environment, which meant that the central banks of these countries were unable to reduce such rates in response to the COVID-19 outbreak. On the other hand, the banks that kept their interest rates higher, which include the Fed and the National Bank of Poland, reacted to the biological and medical crisis in the same way as they did to the financial one, by cutting their interest rates to zero. As a consequence many central banks in developed economies are no longer in a position to deploy standard monetary policy instruments. In this way, the COVID-19 pandemic has perpetuated the near-zero interest rate policy.

\section{Conclusion}

The COVID-19 pandemic has come as a shock that is certain to upset the global economy. This is because the crisis threatens not only global finances, but also, and primarily so, human health and life. The protracted struggle is wreaking havoc with societies both physically and mentally, forcing people to rethink their goal hierarchies, find new perspectives and revise their value systems. The direct and indirect consequences of the pandemic will be felt long after it is gone, while the resulting changes in many areas of our lives may prove permanent.

Will the COVID-19 pandemic be a shock that causes economies to change course and lifts them out of their current sluggishness?

This article aims to focus the debate on the issue at hand by outlining the major precepts of secular stagnation, its historical connotations and the factors commonly 
mentioned in present-day research as having brought developed economies to the point they reached before the outbreak of the coronavirus pandemic.

Considering both its magnitude and its features, it appears likely that the pandemic will change the face of our planet. It is difficult to tell which direction this change is heading as some of the above-mentioned structural factors that are responsible for secular stagnation and the low-interest-rate environment (such as the lack of breakthrough innovations) may well lose relevance. On the other hand, there are also factors (such as income inequalities) whose significance may grow.

All this makes the future of economies highly uncertain. While the pandemic may lift economies out of their current torpor, it may just as well have the opposite effect. Secular stagnation may become a stepping stone towards a new paradigm, setting the course towards a new world. In either case, it seems certain that there is no avoiding the severe crisis that will descend as a natural consequence of the isolation of economies and of the lockdowns and other preventive measures imposed by states. Any long-term forecasting at this point makes little sense.

\section{References}

Baldwin R., di Mauro B.W. (2020), Introduction, [in:] R. Baldwin, B.W. di Mauro (eds.), Economics in the Time of COVID-19, CEPR Press, pp. 1-30.

Baldwin R., Tomiura E. (2020), Thinking ahead about the trade impact of COVID-19, [in:] R. Baldwin, B.W. di Mauro (eds.), Economics in the Time of COVID-19, CEPR Press, pp. 59-71.

Bean C.R., Broda C.M., Itō T., Kroszner R. (2015), Low for long? Causes and consequences of persistently low interest rates, ICMB, International Center for Monetary and Banking Studies.

Boone L. (2020), Tackling the fallout from COVID-19, [in:] R. Baldwin, B.W. di Mauro (eds.), Economics in the Time of COVID-19, CEPR Press, pp. 37-44.

Caballero R.J., Hoshi T., Kashyap A.K. (2008), Zombie lending and depressed restructuring in Japan, American Economic Review, vol. 98, no. 5, pp. 1943-1977.

Caballero R.J., Fargi E. (2014), On the role of safe asset shortages in secular stagnation, [in:] C. Teulings, R. Baldwin (eds.), Secular Stagnation: Facts, Causes and Cures, London: CEPR Press, pp. 111-122.

Centers for Disease Control and Prevention (2020), People who are at higher risk for severe illness. Access: https://www.cdc.gov/coronavirus/2019-ncov/need-extra-precautions/people-at-higher-risk. html.

Dach Z. (2011), Polityka makroekonomiczna w warunkach kryzysu i jej wptyw na gospodarke. Teoria i praktyka, Oficyna a Wolters Kluwer business, Warszawa.

di Mauro B.W. (2020), Macroeconomics of the flu, [in:] R. Baldwin, B.W. di Mauro (eds.), Economics in the Time of COVID-19, CEPR Press, pp. 31-35.

Eichengreen B. (2014), Secular stagnation: A review of the issues, [in:] C. Teulings, R. Baldwin (eds.), (2014). Secular Stagnation: Facts, Causes and Cures, CEPR Press, London, pp. 41-46.

Eichengreen B. (2015), Secular stagnation: the long view, American Economic Review, 105(5), pp. 66-70.

Forbes K. (2015), Low interest rates: King Midas'golden touch, Speech at The Institute of Economic Affairs, London. 
Frąckowiak W. (2020), Pandemia i co dalej?, Studio Opinii, https://studioopinii.pl/archiwa/198074.

Glapiak E. (2020), Koronawirus wywraca świat do góry nogami. Wiele zmian zostanie z nami na zawsze. Access: https://businessinsider.com.pl/.

Golec P., Perotti E. (2017), Safe assets: a review, ECB working paper (No. 2035).

Gordon R.J. (2012), Is US economic growth over? Faltering innovation confronts the six head-winds, NBER Working Paper Series, no. 18315.

Gordon R.J. (2014), The turtle's progress: Secular stagnation meets the headwinds, [in:] C. Teulings, R. Baldwin (eds.), Secular Stagnation: Facts, Causes and Cures, CEPR Press, London, pp. 47-59.

Greenlaw D., Hamilton J.D., Hooper P., Mishkin F.S. (2013), Crunch time: Fiscal crises and the role of monetary policy, NBER Working Paper Series, nr 19297.

Hansen A.H. (1934), Capital goods and the restoration of purchasing power, Proceedings of the Academy of Political Science, 16(1), pp. 11-19.

Hansen A.H. (1939), Economic progress and declining population growth, The American Economic Review, 29(1), pp. 1-15.

Higgins B. (1950), The concept of secular stagnation, The American Economic Review, vol. 40, no. 1 , pp. 160-166.

IMF, (2014a), Is it time for an infrastructure push? The macroeconomic effects of public investment, section 3, [in:] World Economic Outlook: Legacies, Clouds, Uncertainties, October.

IMF, (2014b), Perspective on global real interest rates, section 3, [in:] World Economic Outlook: Recovery strengthens, remains uneven, April.

Javorcik B. (2020), Wywiad z prof. Beata Javorcik prowadzony przez Grzegorza Sroczyńskiego. Access: https://audycje.tokfm.pl/podcast/88314,Jedna-z-najwazniejszych-ekonomistek-na-swiecie-Teraz-trzeba-wydac-duzo-inaczej-nie-przetrwamy.

Lovelace Jr. B. (2020), The coronavirus may be deadlier than the 1918 flu: Here's how it stacks up to other pandemics. Access: https://www.cnbc.com/2020/03/26.

Marczewski K. (2017), Hipoteza o stagnacji sekularnej, Studia Ekonomiczne, no. 4, pp. 377-398.

Mączyńska E. (2015), Potencjat rozwojowy Polski w kontekście hipotezy o nowej sekularnej stagnacji, Biuletyn Polskiego Towarzystwa Ekonomicznego, no. 2.

PWN, Access: https://encyklopedia.pwn.pl/haslo/Antarktyda-Odkrycia-i-podroze;4019566.html.

Rachel L., Smith T. (2015), Secular drivers of the global real interest rate, Staff Working Paper No. 571, Bank of England.

Rzońca A. (2014), Kryzys banków centralnych. Skutki stopy procentowej bliskiej zera, Wydawnictwo C.H. Beck, Warszawa.

Samuelson P.A. (1988), The Keynes-Hansen-Samuelson multiplier-accelerator model of secular stagnation, Japan and the World Economy, vol. 1, no. 1, pp. 3-19.

Smit S., Hirt M., Buehler K., Lund S., Greenberg E., Govindarajan A. (2020), Safeguarding our lives and our livelihoods: The imperative of our time. Access: https://www.mckinsey.com/business-functions/strategy-and-corporate-finance/our-insights/safeguarding-our-lives-and-our-livelihoods-the-imperative-of-our-time?cid=eml-web\#.

Summers L.H. (2013), Speech at: IMF Fourteenth Annual Research Conference in Honor of Stanley Fischer. Access: http://larrysummers.com/imf-fourteenth-annual-research-conference-in-honor-of-stanley-fischer.

Summers L.H. (2014), Reflections on the New Secular Stagnation Hypothesis, [in:] C. Teulings, R. Baldwin (eds.), Secular Stagnation: Facts, Causes and Cures, CEPR Press, London, pp. 27-38.

Summers L.H. (2016), The age of secular stagnation, Foreign Affairs, tom 95, nr 2, Mar/Apr, New York, 2-9.

Summers L.H. (2018), Secular stagnation and macroeconomic policy, IMF Economic Review, 66(2), pp. 226-250.

Teulings C., Baldwin R. (eds.) (2014), Secular Stagnation: Facts, Causes and Cures, CEPR Press, London. 


\section{STAGNACJA SEKULARNA A COVID-19}

Streszczenie: Głównym celem artykułu jest rozpoczęcie dyskuji o pandemii COVID-19 w kontekście zjawiska stagnacji sekularnej. Stagnacja sekularna została przywołana przez Lawrence'a Summersa w 2013 roku. Summers stwierdził bowiem, że po globalnym krachu finansowym lat 2007-2009 gospodarki zostały uwięzione w erze mozolnego i niskiego wzrostu gospodarczego oraz w środowisku niskich stóp procentowych. Obecnie, kiedy koronawirus zaatakował społeczeństwa, wiele sytuacji, procesów czy działań uległo zmianie, dlatego autorzy próbują przeanalizować potencjalny wpływ pandemii koronawirusa na czynniki strukturalne, które uznawane są za źródła stagnacji sekularnej. Autorzy stwierdzili, że pandemia może być wydarzeniem zwrotnym, które zmieni globalną ekonomię, ale charakter kryzysu sprawia, iż bardzo trudno przewidzieć ostateczne efekty.

Słowa kluczowe: stagnacja sekularna, kryzys, pandemia, COVID-19. 